\title{
Agreement between two Meal Quality Indexes adapted to evaluate food consumption of institutionalized elderly
}

\section{Concordância entre dois Índices de Qualidade da Refeição adaptados para avaliar o consumo alimentar de idosos institucionalizados}

\author{
Rebecca Garcia GERMOGLIO1 (iD) 0000-0003-1419-5139 \\ Severina Carla Vieira Cunha LIMA² iD 0000-0001-8268-1986

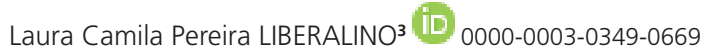 \\ Natália Louise de Araújo CABRAL ${ }^{3}$ iD 0000-0002-9166-1917 \\ Kenio Costa de LIMA4 (D) 0000-0002-5668-4398 \\ Clélia de Oliveira LYRA² (iD) 0000-0002-1474-3812
}

A B S T R A C T

\section{Objective}

To assess agreement between two meal quality indexes adapted for elderly people, evidencing their similarities and differences.

\footnotetext{
1 Universidade Federal do Rio Grande do Norte, Centro de Ciências da Saúde, Programa de Pós-Graduação em Nutrição. Natal, RN, Brasil.

2 Universidade Federal do Rio Grande do Norte, Centro de Ciências da Saúde, Departamento de Nutrição. Av. Senador Salgado Filho, 3000, Campus Universitário, Lagoa Nova, 59078-970, Natal, RN, Brasil. Correspondence to: CO LYRA. E-mail: <clelia_lyra@yahoo.com.br>.

3 Universidade Federal do Rio Grande do Norte, Centro de Ciências da Saúde, Programa de Pós-Graduação em Saúde Coletiva. Natal, RN, Brasil.

${ }^{4}$ Universidade Federal do Rio Grande do Norte, Centro de Ciências da Saúde, Departamento de Odontologia. Natal, RN, Brasil.

Support: Fundação de Apoio à Pesquisa do Estado do Rio Grande do Norte (FAPERN/CNPq document 003/2011), Programa de Apoio a Núcleos Emergentes (number process n ${ }^{\circ}$ 77228/2013), and Coordenação de Aperfeiçoamento de Pessoal de Nível Superior - Finance Code 001.

Article based on the dissertation of RG GERMOGLIO, entitled "Qualidade da refeição consumida por idosos institucionalizados em Natal, RN - Brasil". Universidade Federal do Rio Grande do Norte; 2018.
}

How to cite this article

Germoglio RG, Lima SCVC, Liberalino LCP, Cabral NLA, Lima KC, Lyra CO. Agreement between two Meal Quality Indexes adapted to evaluate food consumption of institutionalized elderly. Rev Nutr. 2019;32:e180127. http://dx.doi. org/10.1590/1678-9 865201932e180127 


\section{Methods}

Agreement study with 322 institutionalized elderly individuals. Food consumption data were collected by the method of weighted food record, in two nonconsecutive days. The Meal Quality Index and the Main Meal Quality Index of each older adult were calculated for the lunch meal. Agreement between methods was tested by cross-classification in quartiles and weighted kappa $(\mathrm{Kw})$, and the difference between medians by the Wilcoxon test.

\section{Results}

The Meal Quality Index median was 54.67 points and the Main Meal Quality Index 53.51 points $(p=0.723)$. When the components of each index were assessed, those associated to the consumption of carbohydrates, total fat and saturated fat were similar. The consumption of fruits separated from vegetables in the Main Meal Quality Index evidenced low consumption of vegetables by the elderly. Cross-classification by quartiles showed good agreement; the exact one being $48.8 \%$ and the disagreement $3.4 \%\left(K_{w}=0,447\right)$. The proportion of elderly individuals in the same exact or adjacent quartile was greater than $85.0 \%$. Agreement was higher in males $\left(89.4 \%, K_{w}=0.475\right)$; in the age range of 70 to 79 years $\left(91.1 \% ; K_{w}=0.562\right)$ and in non-profit nursing homes $\left(96.7 \% ; K_{w}=0.622\right)$.

\section{Conclusion}

The two indexes reviewed show a good agreement between them and common characteristics. The number of components is higher in the MMQI and may represent a more detailed assessment of meal quality.

Keywords: Lunch. Elderly. Meal quality. Meals.

\section{RE S U M O}

\section{Objetivo}

Avaliar a concordância entre dois índices de qualidade da refeição adaptados para idosos, evidenciando suas semelhanças e diferenças.

\section{Métodos}

Estudo de concordância realizado com 322 idosos institucionalizados. Os dados de consumo alimentar foram coletados pelo método de registro alimentar por pesagem, em dois dias não consecutivos. Foram calculados o Índice de Qualidade da Refeição e o Main Meal Quality Index de cada idoso para a refeição do almoço. A concordância entre os métodos foi testada pela classificação cruzada em quartis e kappa ponderado (K $)_{p}$, e a diferença entre medianas pelo teste de Wilcoxon.

\section{Resultados}

A mediana do Índice de Qualidade da Refeição foi de 54,67 pontos e do Main Meal Quality Index foi de 53,51 pontos $(p=0,723)$. Quando avaliado os componentes de cada índice, os relacionados ao consumo de carboidratos, gordura total e gordura saturada foram semelhantes. O componente frutas, separado das verduras no Main Meal Quality Index evidenciou o baixo consumo de verduras pelos idosos. A classificação cruzada por quartis mostrou boa concordância, sendo a exata de $48,8 \%$ e a discordância de $3,4 \%\left(K_{p}=0,447\right)$. A proporção de idosos no mesmo quartil ou quartil adjacente foi de mais de 85,0\%. A concordância foi maior no sexo masculino (89,4\%; $\left.K_{p}=0,475\right)$; na faixa etária de 70 a 79 anos $\left(91,1 \% ; K_{p}=0,562\right)$ e nas instituições sem fins lucrativos $\left(96,7 \% ; K_{p}=0,622\right)$.

\section{Conclusão}

Os dois índices analisados tem uma boa concordância entre si e características em comum. O número de componentes é maior no MMQI, podendo representar avaliação mais detalhada da qualidade da refeição.

Palavras-chave: Almoço. Idoso. Qualidade da refeição. Refeições.

\section{NTROD U C T I O N}

Brazilian population has experienced a changing process in age structure due to the decrease in fertility levels and increase in life expectancy, leading to a greater population aging $[1,2]$. This 
demographic transition has led to an increase in the provision of formal care services, among which Long-term Care Institutions for the Elderly (LTCI) [3].

In the city of Natal, Rio Grande do Norte, located in the northeastern region of Brazil, institutionalized elderly people are characterized for being, for the most part, non-literate, retired and resident in non-profit institutions, which are associated with worse socioeconomic conditions, reflecting the social inequality in this field [4]. The health profile of these elderly people is marked by high incidence of diseases, cognitive incapacity, depression, functional capacity decline during the institutionalization term and restrictions in daily activities capacity [5-8].

It is important to emphasize that aging is a natural process involving anatomical and functional changes, with repercussions on the health conditions and the nutritional status of the elderly [9]. Additionally, institutionalization imposes changes in the routine of elderly people that can change their dietary habits and influence their health fragility, due to reduced food acceptance and consequent impairment of their nutritional status $[10,11]$.

Healthy food intake is a primary factor in fostering and maintaining healthy conditions throughout life, being one of the main factors capable of conditioning quality of life and longevity $[1,12]$. Since feeding takes place on food occasions that are composed of different foods with complex nutrient combinations that interact with each other, understanding the nutritional composition of meals and their impact on diet quality is essential $[13,14]$. In addition, meal patterns represent interactions between food and environment, as well as with genetics, personality, circadian rhythm and social determinants, and are associated with different diseases [15].

The quality of food and of meals can be assessed by means of consumption patterns, by a priori dietary indexes, such as the Meal Quality Index (MQI) [16] and the Main Meal Quality Index (MMQI) [17]. However, there is a lack of dietary indexes to evaluate the meal quality of the elderly, especially of those institutionalized, since no index applied to this target audience has been found in the literature to date $[18,19]$.

The MQI was proposed to review the quality of the meals offered to workers by the Programa de Alimentação do Trabalhador (PAT, Workers' Food Program), and its use is interesting to assess collectivities, while the MMQI proposes an assessment of the quality of the main meal in different frameworks and populations $[16,17]$. Thus, the present study aims at reviewing the agreement between the two above mentioned meal quality indexes, highlighting their similarities and differences.

\section{METHODS}

This is a concordance rate study nested in a cross-sectional, population-based, census-based study at Long-Term Care Institutions for The Elderly (LTCI) in the city of Natal (RN), Brazil. The study population includes all residents aged 60 years and older who were not on exclusive enteral nutrition. Out of the 415 residents in the city's 14 LTCI during the period 2013 - 2014, five were not elderly (less than 60 years), 13 were enteral-supported, and 75 did not agree to participate in the survey, totaling 322 eligible older people in $10 \mathrm{LTCI}$.

This study is linked to the "Human Aging and Health Project: The Reality of the Institutionalized Elderly People in Natal Municipality, RN", approved by the Research Ethics Committee (Central Committee) of the Federal University of Rio Grande do Norte, with Presentation Certificate for Ethical Appraisal (CAAE) number 0290.0.051.000-11, approved according to Opinion No. 308/2012. 
Food consumption data were collected by a previously trained technical team using the Dietary Record (DR) method of direct food weighing, in two nonconsecutive days. Food consumption was recorded through standardized portions counting.

By direct observation, it was checked whether the elderly repeated, switched food with other older persons, consumed some other food that was not on the menu, refused the preparations or left some food in their plate. The amount of food consumed (in grams) was determined by the difference between the quantity offered and the left over.

Afterwards, a standardization of the foods consumed was carried out to make the different modes of preparation and commercial brands uniform, thus minimizing errors in the review of the dietary intake.

\section{Analysis of food consumption data}

For the review of the Preparation Technical Sheets, a hybrid food composition table was generated in Excel ${ }^{\circledast}$ (Microsoft, Office Package, version 2013), using the nutrient information available in the Brazilian Table of Food Composition - TACO [20] supplemented with data of the nutrients folate, selenium, vitamin B12, vitamin D and vitamin E obtained from the United States Department of Agriculture (USDA, Release 27) [21], which are not available in the Brazilian table.

Subsequently, food was analyzed in the virtual environment of the Virtual Nutri Plus ${ }^{\circledR}$ software and a spreadsheet of the final consumption of each elderly individual was prepared, containing the standardized foods, the final amount consumed and their chemical composition.

\section{Quality of the meal}

The quality of the meal was assessed by the Meal Quality Index [16] and the Main Meal Quality Index [17], which were chosen because they have been developed for and applied to the Brazilian population $[16,22]$ Chart 1. In addition, it was decided to analyze the lunch meal since it represents the main meal in Brazil $[22,23]$ and, in order to allow comparisons, it was the meal analyzed in both indexes.

Such indexes were adapted to the elderly in terms of carbohydrates, total fat and saturated fat components consumption following the recommendations of the Brazilian Dyslipidemia and Prevention of Atherosclerosis Guideline - 2017. Changes involved: the carbohydrates component that was expected to supply 55 to $75 \%$ of the total calories intake and turned then to be reduced to a consumption of 50 to $60 \%$ as being appropriate; the total fat component increased from $15-30 \%$ to $25-35 \%$ and the saturated fat component decreased from $10-13 \%$ to $7-10 \%$ [24]. In addition, the MQI was adapted to assess the foods consumed, since this method originally assesses the foods offered.

Scores were distributed proportionally between the minimum and maximum values, so that the highest score represents the closest to the appropriate component's value, according to the formula described below. The maximum total value of the two indexes is 100 points.

$$
\begin{aligned}
& Y=\frac{P^{\star}\left(X-V_{\min }\right)}{\left(V_{\max }-V_{\min }\right)} \\
& \text { Y: Score to be determined } \\
& P \text { : Maximum component score } \\
& \mathrm{X} \text { : Consumed amount } \\
& V_{\max }: \text { Value of the component that equals the maximum score } \\
& V_{\min } \text { : Value of the component that equals } 0 \text { Score }
\end{aligned}
$$


Chart 1. Components of the Meal Quality Index (MQI) and of the Main Meal Quality Index (MMQI).

\begin{tabular}{|c|c|c|}
\hline \multirow{2}{*}{ Indicator } & \multicolumn{2}{|c|}{ Scores } \\
\hline & Minimum & Maximum \\
\hline \multicolumn{3}{|l|}{$M Q^{a}$} \\
\hline Fruits and vegetables consumption & Consumption $\leq 80 \mathrm{~g}$ with score 0 . & Consumption $\geq 160 \mathrm{~g}$ with score 20 . \\
\hline Carbohydrates consumption ${ }^{c}$ & Consumption $\leq 40 \%$ or $\geq 75 \%$ with score 0 . & $\begin{array}{l}\text { Consumption between } 50 \% \text { and } 60 \% \text { with } \\
\text { score } 20 \text {. }\end{array}$ \\
\hline Total fat consumption ${ }^{c}$ & Consumption $\geq 40 \%$ or $\leq 15 \%$ with score 0 . & $\begin{array}{l}\text { Consumption between } 25 \% \text { and } 30 \% \text { with } \\
\text { score } 20 \text {. }\end{array}$ \\
\hline Saturated fat consumption ${ }^{c}$ & Consumption $\geq 10 \%$ with score 0 . & Consumption $\leq 7 \%$ with score 20 . \\
\hline Meal variability & $\begin{array}{l}\text { Meal with less than } 4 \text { food and } 2 \text { groups } \\
\text { with score } 0 \text {. }\end{array}$ & $\begin{array}{l}\text { Meal with at least } 11 \text { different food and } 5 \\
\text { different groups received score } 20 \text {. }\end{array}$ \\
\hline \multicolumn{3}{|l|}{$M M Q I^{\mathbf{b}}$} \\
\hline Fruits consumption & Consumption de $0 \mathrm{~g}$ with score 0. & Consumption $\geq 80 \mathrm{~g}$ with score 10 . \\
\hline Vegetables consumption & Consumption $\leq 80 \mathrm{~g}$ with score 0 . & Consumption $\geq 160 \mathrm{~g}$ with score 10 . \\
\hline Animal protein/total protein & $\begin{array}{l}\text { Ratio between animal protein and total } \\
\text { protein consumption }=100 \% \text { with score } 0 .\end{array}$ & $\leq 80 \%$ with score 10 . \\
\hline Fiber & Consumption $\leq 7 \mathrm{~g}$ with score 0 . & Consumption $\geq 10 \mathrm{~g}$ with score 10 . \\
\hline Carbohydrates consumption ${ }^{c}$ & Consumption $\leq 40 \%$ or $\geq 75 \%$ with score 0 . & $\begin{array}{l}\text { Consumption between } 50 \% \text { and } 60 \% \text { with } \\
\text { score } 10 \text {. }\end{array}$ \\
\hline Total fat consumptionc & Consumption $\geq 40 \%$ or $\leq 15 \%$ with score 0 . & $\begin{array}{l}\text { Consumption between } 25 \% \text { and } 30 \% \text { calories } \\
\text { with score } 10 \text {. }\end{array}$ \\
\hline Saturated fat consumption ${ }^{c}$ & Consumption $\geq 10 \%$ with score 0 . & Consumption $\leq 7 \%$ with score 10 . \\
\hline Processed meat & $\begin{array}{l}\text { Consumption of } 1 \text { or more portions with } \\
\text { score } 0 .\end{array}$ & No intake with score 10. \\
\hline Desserts and sweetened drinks & $\begin{array}{l}\text { Consumption of } 1 \text { or more portion with } \\
\text { score } 0 .\end{array}$ & No intake with score 10. \\
\hline Energy Density & $\begin{array}{l}\text { Meal energy density } \geq 1,65 \mathrm{kcal} / \mathrm{g} \text { with } \\
\text { score } 0 \text {. }\end{array}$ & Meal energy density $\leq 1,25 \mathrm{kcal} / \mathrm{g}$ with score 10 . \\
\hline
\end{tabular}

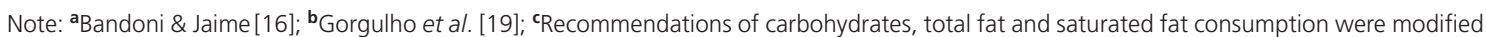
for the age group of the elderly population ( $\geq 60$ years) (Faludi et al. [24]).

\section{Statistical analysis}

First, variables normality was verified using the Kolmogorov-Sminorv test, which indicates that the data referring to the two indexes assessed did not exhibit a normal distribution. To assess the statistical significance of all the tests, the value of $p<0.05$ was considered.

The study population was characterized according to gender, age, and type of LTCI by absolute and percentage frequencies. Quartiles were calculated for each index and were plotted in boxplot charts. To assess agreement between the two meal quality indexes, the Wilcoxon test was used, considering differences to be significant when $p<0.05$.

The medians of all the components of the indexes were calculated, in order to assess similarities and differences of each index components. In addition, the percent frequencies were calculated to demonstrate the relative contribution of each component to the final score.

The scores of each elderly individual were classified in the intervals between the quartiles calculated for each of the quality indexes of the meal (1 ${ }^{\text {st }}$ Interval -0 to P25, $2^{\text {nd }}$ Interval - P25 to 
P50, $3^{\text {rd }}$ Interval - P50 to P75; 4th Interval - P75 to P100). Agreement between the two methods was tested by cross-classification of such classification between the two indexes and the weighted kappa was calculated. The kappa classification criteria used were those of Landis and Koch [25]. In addition, the proportion of elderly persons classified in the same consumption quartile in the two methods (exact agreement), in the same quartile and in the adjacent quartiles (exact + adjacent agreement) and opposite quartiles (disagreement) were assessed.

\section{R S U L T S}

The population analyzed was predominantly female (74.0\%) and the majority resided in non-profit institutions (66.5\%). Regarding age, more than half (58.5\%) were over 80 years old, $29.0 \%$ were between 70 and 79 years old, and $12.5 \%$ were between 60 and 69 years old (data not shown in the Table).

The median MQI was 54.67 points and the MMQI was 53.51 points. There were no statistically significant differences between the two indexes $(p=0.723)$. However, it should be pointed out that the MQI exhibited greater data dispersion than the MMQI (Figure 1).

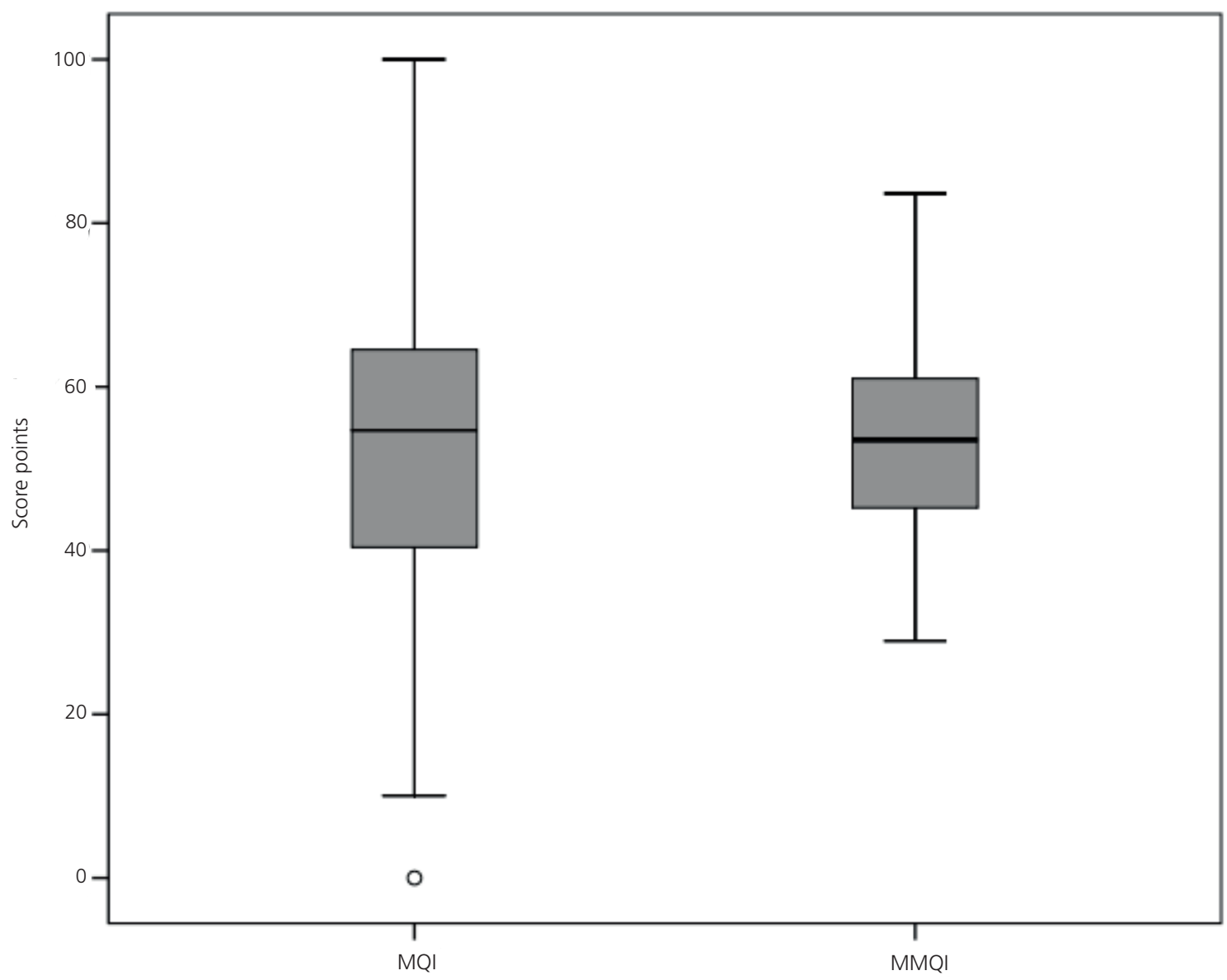

Figure 1. Score comparison of two meal quality indexes among institutionalized elderly. Natal (RN), 2013. Note: MQI: Meal Quality Index; MMQI: Main Meal Quality Index. 
MQI and MMQI and their corresponding components are detailed in Table 1. Carbohydrate, total fat and saturated fat components were proportionally similar considering that the MQI score was practically the double of the MMQI, a difference derived solely by the scales of values used in the indexes - in the MQI each component varies from 0 to 20 , while in the MMQI it varies from 0 to 10. Thus, the scores of each component have a greater relative contribution to the total score in the MQI than in the MMQI, considering that the MQI exhibits fewer components. It is noteworthy that when showing fruit consumption separated from vegetables in the MMQI, a low consumption of vegetables was evidenced in the elderly. In addition, the components contained in the MMQI allowed to observe other aspects of the elderly diet quality: higher median scores for the components "Desserts and sweetened drinks", "Processed meats" and "Animal / total protein ratio", indicated a good quality for these items and lower scores for "Energy Density". It should be noted that the

Table 1. Median score and relative percentage of total components of the Meal Quality Index (MQI) and of the Main Meal Quality Index (MMQI). Natal (RN), 2013.

\begin{tabular}{lcclcc}
\hline MQI & Score & \% of total & & Score & \% of total \\
\hline Carbohydrates & 8.26 & 14.93 & Carbohydrates & 4.13 & 7.85 \\
Total fat & 10.00 & 18.07 & Total fat & 5.00 & 9.51 \\
Saturated fat & 14.67 & 26.51 & Saturated fat & 7.34 & 13.96 \\
Fruits, vegetables, greens & 10.50 & 18.98 & Fruits & 5.00 & 9.51 \\
& & & Vegetables & 0.00 & 0.00 \\
Meal variability & \multirow{2}{*}{21.51} & Desserts and sweetened drinks & 10.00 & 19.01 \\
& & & Processed meats & 10.00 & 19.01 \\
& & & Fiber & 1.40 & 2.66 \\
& & & Animal protein / total & 9.72 & 18.49 \\
& & & Energy density & 0.00 & 0.00 \\
\hline Total & \multirow{2}{*}{55.33} & 100.00 & Total & 52.59 & 100.00 \\
\hline
\end{tabular}

Table 2. Cross-classification of the Meal Quality Index (MQI) vs. Main Meal Quality Index (MMQI) according to gender, age group and type of Long Term Care Institutions for the Elderly (LTCI). Natal (RN), 2013.

\begin{tabular}{|c|c|c|c|c|c|c|c|}
\hline \multirow{2}{*}{ Variables/Categories } & \multirow{2}{*}{ Weighted Kappa } & \multicolumn{2}{|c|}{ Exact agreement ${ }^{a}$} & \multicolumn{2}{|c|}{ Exact agreement + adjacent ${ }^{\mathbf{b}}$} & \multicolumn{2}{|c|}{ Disagreement ${ }^{c}$} \\
\hline & & $\mathrm{n}$ & $\%$ & $n$ & $\%$ & $n$ & $\%$ \\
\hline \multicolumn{8}{|l|}{ Gender } \\
\hline Male & 0.475 & 39 & 46.5 & 75 & 89.4 & 2 & 2.4 \\
\hline Female & 0.437 & 118 & 49.6 & 201 & 84.5 & 9 & 3.8 \\
\hline \multicolumn{8}{|l|}{ Age Group } \\
\hline $60-69$ years & 0.452 & 17 & 43.5 & 35 & 89.7 & 1 & 2.6 \\
\hline 70-79 years & 0.562 & 52 & 57.8 & 82 & 91.1 & 1 & 1.1 \\
\hline 80 years or + & 0.371 & 82 & 44.9 & 150 & 82.0 & 9 & 4.9 \\
\hline \multicolumn{8}{|l|}{ LTCI type } \\
\hline Non-profit & 0.622 & 122 & 57.0 & 207 & 96.7 & 0 & 0.0 \\
\hline For-profit & 0.074 & 35 & 32.5 & 69 & 63.9 & 11 & 10.2 \\
\hline Total & 0.447 & 157 & 48.8 & 276 & 85.7 & 11 & 3.4 \\
\hline
\end{tabular}

Note: ${ }^{a}$ Classification in the same quartile; ${ }^{\mathbf{b}}$ Classification in the same quartile and in adjacent quartiles; ${ }^{\mathbf{c}} \mathrm{Classification}$ in opposing quartiles. LTCI: Long Term Care Institutions for the Elderly. 
component that contributed most in the total score was saturated fat in the MQI, and desserts and sweetened beverages and processed meats in the MMQI.

The cross-classification of the two indexes according to gender, age group and type of LTCI is shown in Table 2. In general, most of the individuals exhibited good agreement between the two indexes, being classified in the same quartile or in the adjacent one (85.7\%). Disagreement between methods was low (3.4\%). Agreement was higher in males (89.4\%, weighted kappa $=0.475)$; in the age group of 70 to 79 years $(91.1 \%$; weighted kappa $=0.562)$ and in the non-profit LTCIs $(96.7 \%$; weighted kappa $=0.622$ ).

\section{DISCUSSION}

This pioneer study assessed the agreement between two dietary indexes of meal quality evaluation in elderly people living in LTCls of a capital city in Northeast Brazil. Agreement between the instruments was tested with different approaches. Initially, individuals' classification into quartiles was performed in order to show the degree of agreement between the methods. High agreement was observed, with more than $85 \%$ of the individuals classified in the same or adjacent quartiles.

According to the Kappa classification proposed by Landis and Koch [25], the observed agreements were moderate for total classification, male gender, non-profit institutions and age group between 70 and 80 years (kappa between 0.41 and 0.60) and regular for the female gender and age groups between 60 and 70 years and over 80 years of age (kappa between 0.21 and 0.40 ), and weak agreement was verified only in the case of for-profit institutions. The weighted kappa values showed reasonable agreement between the methods. These results are consistent with the literature data when it comes to food consumption [26-28].

It is important to note that, likewise, when used in validation and reproducibility studies of food survey instruments, participants' classification according to the quartile distribution can both group individuals with different levels of meal quality into the same category, as well as put into different categories those with similar levels, if they are very close to the cut-off point [29]. Since the sample size used was within the range recommended for validation studies, there is a relative reduction of this bias [30].

Thus, the two indexes evaluated showed good agreement between them, indicating that the use of either indexes would produce very similar results regarding the assessment of meal quality, considering the scores. However, it is necessary to consider the applicability of each index, as well as qualitatively assess the best to be used in each situation.

MQI has fewer components, which may restrict a more detailed analysis of the meal. Therefore, each component of the MQI has a higher relative contribution to the overall score, so that few items with high scores may excessively increase the final score. For example, when it comes to the quality of the elderlies' meal, adequate macronutrient consumption scores may mask the result of low fruit and vegetable intake or food monotony.

Regarding the information generated, both indexes review items that are relevant to the current health context, such as total and saturated fat and carbohydrates consumption. MQI allows assessing the condition of food monotony through the item Variability. However, it has the limitation that this component classifies as adequate a meal with many foods and food groups, leading to questioning if the amount proposed would be adequate to be ingested in only one meal. 
Another point assessed was the applicability of the index in the different phases of life. The MQI, because it was developed for corporate workers, can be adapted to other types of collectivities. However, it is difficult to use it in other population groups due to its specificity.

Originally the MQI method assessed the meal offered, which may be different from the meal consumed. The proposal being an assessment of collective feeding, like the PAT, can contribute to the assessment of the effectiveness of food and nutrition policies for workers. In the case of the institutionalized elderly, supply may be close to consumption, which would not imply in an important analysis difference from the point of view of food consumption.

In relation to the MMQI, the MQI includes more components, allowing a more detailed assessment of a meal features and has a smaller relative contribution of each component to the total.

The MMQI does not have a specific component to discuss food variability; however, the components included in this index may contribute to the review of food monotony. The MMQI analyzes important items such as excessive consumption of animal protein, besides positively evaluating minimally processed foods and related nutrients (fruits, vegetables, fiber) and negatively the consumption of food and nutrients harmful to health (processed meat, saturated fat, desserts and sweetened drinks).

About the applicability in life stages, although developed for the adult population, the MMQI comprises important components for all age groups and population groups.

Regarding macronutrients, both indexes assessed the consumption of carbohydrates, total fat and saturated fat. Analysis of these macronutrients is of basic importance for elderly people's health, considering that, when in excess, they are associated with the occurrence of diabetes, arterial hypertension, obesity, cardiovascular diseases, among others. However, only MMQI has a component related to protein quality, which is an essential macronutrient in the diet of the elderly, since low amounts of animal protein in the diet are associated with sarcopenia, muscular loss, malnutrition, fragility, falls and dependency in older people [31,32].

In the MQI's component of fruits and vegetables, it was observed that, because it was aggregated, it was not evident that, out of the main dietary fiber sources, the population assessed consumed only fruits, and not the three types of food, as recommended by the Food Guide for the Brazilian population [33]. In the MMQI, this analysis is possible because the components "fruits" and "vegetables" are separated, being this another positive point of such index.

Another advantage of the MMQI is that it presents components related to the risk of cardiometabolic diseases development, such as ultra processed foods (processed meat and stuffed food), sweets and sweetened beverages [22,23,32].

In addition, the MMQI assesses the energy density of meals consumed by the elderly. Studies indicate that collective meals geared to ill or hospitalized individuals, energy density can be used for obesity and chronic diseases treatment, helping in the nutritional status recovery and in the process of weight gain, since malnutrition is common in hospitalized patients, as well as in the institutionalized elderly $[3,34]$. Foods with high energy density like potatoes, biscuits and meat products have a high fat or sugar content, while foods with reduced energy density have more water in their composition, such as fruits, vegetables and soups. Thus, energy density is also associated with diet quality $[35,36]$.

The authors acknowledge that the assessment of food consumption may present measurement errors due to the nature of this type of information. However, the study has as strong points 
the method of collecting food consumption data from food records by weighing, which already eliminates a few biases that impair indirect methods. In addition, the survey was carried out in 10 out of 14 Long-term Residency Institutions in the municipality, representing $77.6 \%$ of the population at the time of data collection, which allowed an overview of the institutionalized older people in the municipality and enhancing the pioneering nature of the study, because there is no other study comparing meal indexes.

The search for food standards classification through indexes is continuous, since feeding is a multidimensional phenomenon [37]. These indexes allow the simultaneous assessment of food and nutrient intake, allowing an indirect analysis of meal components without a reduction to a single item [16].

The limited knowledge of the food situation of the elderly in Brazil considering the new demographic reality requires further investigation [38]. Studies of this nature about nutritional quality of meals for the elderly, especially the institutionalized ones, have not been published to-date, thus highlighting the relevance of this study.

\section{CONCLUSION}

The findings of this study indicate that the two meal quality indexes reviewed have a good agreement between them, so that the use of any of the two would result in similar review outcomes, considering the scores. However, the MMQI exhibits a more detailed assessment of the meal quality because it includes a greater number and combination of components, allowing the assessment of both risk and protection factors for the development of chronic non-communicable diseases.

\section{CONTRIBUTORS}

RG Germoglio contributed with the conception, design, review and interpretation of the data, article writing and critical review of the intellectual content. LCP Liberalino and NLA Cabral contributed with the critical review of the intellectual content. KC Lima, SCVC Lima and CO Lyra contributed with data analysis and interpretation, article writing and critical review of the intellectual content. All the authors evaluated and approved the final version to be published.

\section{REFERENCES}

1. Coelho CNV, Schneider BC, Cascaes AM, Silva AER, Orlandi SP. Consumo alimentar de idosos atendidos em um programa de reabilitação da saúde bucal de unidades de saúde da família na cidade de Pelotas-RS. RASBRAN: Rev Assoc Bras Nutr. 2017;8(2):43-9.

2. Ribeiro AA, Pessoa MTG, Azevedo SMU, Oliveira VTL, Meireles AL. Caracterização socioeconômica, estado nutricional e prevalência de insegurança alimentar em idosos usuários do restaurante popular de um município do nordeste brasileiro. Rev Ciênc Plural. 2016;2(3):59-71.

3. Silva JL, Marques APO, Leal MCC, Alencar DL, Melo EMA. Fatores associados à desnutrição em idosos institucionalizados. Rev Bras Geriatr Gerontol. 2015;18(2):443-51. http://dx.doi.org/10.1590/1809-982 3.2015.14026

4. Pinheiro NCG, Holanda VCD, Melo LA, Medeiros AKB, Lima KC. Desigualdade no perfil dos idosos institucionalizados na cidade de Natal, Brasil. Ciênc \& Saúde Coletiva. 2016;21(11):3399-405. http://dx.doi. org/10.1590/1413-812320152111.19472015 
5. Jerez-Roig J, Ferreira LMBM, Araújo JRT, Lima KC. Functional decline in nursing home residents: A prognostic study. PLoS One. 2017;12:1-14. http://dx.doi.org/10.1371/journal.pone.0177353.

6. Jerez-Roig J, Medeiros JF, Fidélis KNM, Lima Filho BF, Oliveira NPD, Paes de Andrade FL, et al. Activity Limitations in Brazilian Institutionalized Older Adults. J Geriatr Physical Ther. 2016;40:214-22. http://dx.doi. org/10.1519/JPT.0000000000000101

7. Jerez-Roig J, Oliveira NPD, Lima Filho BF, Farias Bezerra MA, Matias MGL, Ferreira LM, et al. Depressive Symptoms and Associated Factors in Institutionalized Elderly. Experimental Aging Res. 2016;42:479-91. http://dx.doi.org/10.1080/0361073X.2016.1224673

8. Andrade FLJP, Lima JMR, Fidelis KNM, Jerez-Roig J, Lima KC. Cognitive impairment and associated factors among institutionalized elderly persons in Natal, Rio Grande do Norte, Brazil. Rev Bras Geriatr Gerontol. 2017;20:186-96. http://dx.doi.org/10.1590/1981-22562017020.160151

9. Ministério da Saúde (Brasil). Secretaria de Atenção à Saúde. Guia alimentar para a população brasileira: promovendo a alimentação saudável. Brasília: Ministério da Saúde; 2008.

10. Volpini MM, Frangella VS. Avaliação nutricional de idosos institucionalizados. Einstein. 2013;11(1):32-40. http://dx.doi.org/10.1590/S1679-45082013000100007

11. Grøndahl VA, Aagaard H. Older people's involvement in activities related to meals in nursing homes. Int J Older People Nurs. 2016;11(3):204-13. http://dx.doi.org/10.1111/opn.12111

12. Previdelli AN, Goulart RMM, Aquino RC. Balanço de macronutrientes na dieta de idosos brasileiros: análises da Pesquisa Nacional de Alimentação 2008-2009. Rev Bras Epidemiol. 2017;20(1):70-80. http://dx.doi. org/10.1590/1980-5497201700010006

13. Leech RM, Worsley A, Timperio A, McNaughton SA. Understanding meal patterns: definitions, methodology and impact on nutrient intake and diet quality. Nutr Res Rev. 2015;28:1-21. http://dx.doi.org/10.1017/S0 954422414000262

14. Santos RO, Fisberg RM, Marchioni DML, Baltar VT. Dietary patterns for meals of Brazilian adults. Br J Nutr. 2015;114,822-8. http://dx.doi.org/10.1017/S0007114515002445

15. Karatzi K, Yannakoulia M, Psaltopoulou T, Voidonikola P, Kollias G, Sergentanis TS, et al. Meal patterns in healthy adults: Inverse association of eating frequency with subclinical atherosclerosis indexes. Clin Nutr. 2015;34(2):302-8. http://dx.doi.org/10.1016/j.clnu.2014.04.022

16. Bandoni DH, Jaime PC. A qualidade das refeições de empresas cadastradas no Programa de Alimentação do Trabalhador na cidade de São Paulo. Rev Nutr. 2008;21(2):177-84. http://dx.doi.org/10.1590/S1415-52 732008000200006

17. Gorgulho B, Pot GK, Sarti FM, Fisberg RM, Marchioni DM. Measuring quality of meals: development of an index to be used in multicultural context. Ann Nutr Metab. 2015;67(Suppl 1):235-6.

18. Gorgulho BM, Pot GK, Sarti FM, Marchioni DM. Indices for the assessment of nutritional quality of meals: a systematic review. Br J Nutr. 2016;115:2017-24. http://dx.doi.org/10.1017/S0007114516000994

19. Gorgulho BM, Pot GK, Marchioni DM. Evaluation of the psychometric properties of the main meal quality index when applied in the UK population. Eur J Clin Nutr. 2016;71(5):674-6. http://dx.doi.org/10.1038/ ejcn.2016.175

20. Universidade Estadual de Campinas. Tabela Brasileira de Composição de Alimentos (TACO). 4. ed. rev. Campinas: Unicamp; 2011.

21. United States Department of Agriculture. Agricultural Research Service, Nutrient Data Laboratory. National Nutrient Database for Standard Reference (Release 27). Baltimore: USDA; 2014 [cited 2018 Feb 5] Available from: http://ndb.nal.usda.gov/ndb/search/list

22. Gorgulho BM, Santos RO, Teixeira JA, Baltar VT, Marchioni DM. Lunch quality and sociodemographic conditions between Brazilian regions. Cad Saúde Pública. 2018;34(5):e00067417. http://dx.doi.org/10.1590/0102-3 $11 \times 00067417$

23. Gorgulho BM, Pot GK, Sarti FM, Marchioni DM. Main meal quality in Brazil and United Kingdom: Similarities and differences. Appetite. 2017;111:151-7. http://dx.doi.org/10.1016/j.appet.2016.12.038

24. Faludi AA, Izar MCO, Saraiva JFK, Chacra APM, Bianco HT, Afiune Neto A, et al. Atualização da Diretriz Brasileira de Dislipidemias e Prevenção da Aterosclerose 2017. Arq Bras Cardiol. 2017;109(2 Suppl.1):1-76. http://dx.doi.org/10.5935/abc.20170121 
25. Landis JR, Koch GG. The measurement of observer agreement for categorical data. Biometrics. 1977;33(1):159-74. http://dx.doi.org/10.2307/2529310

26. Xia W, Sun C, Zhang L, Zhang X, Wang J, Wang H, et al. Reproducibility and relative validity of a food frequency questionnaire developed for female adolescents in Suihua, North China. Plos One. 2011;6(5). http://dx.doi.org/10.1371/journal.pone.0019656

27. Isobe MT, Bertola MR, Zuccolotto DCC, Sartorelli DS. A influência da escolaridade na reprodutibilidade de um questionário quantitativo de frequência alimentar para gestantes. Rev Bras Saúde Matern Infant. 2013;13(1):23-8.

28. Silva NF, Sichieri R, Pereira RA, Silva RMVG, Ferreira MG. Reproducibility, relative validity and calibration of a food frequency questionnaire for adults. Cad Saúde Pública. 2013;29(9):1783-94. http://dx.doi. org/10.1590/0102-311X00120312

29 Bonatto S, Henn RL, Olinto MTA, Anjos LA, Wahrlich V, Waissmann W. Reprodutibilidade, validade relativa e calibração de um questionário de frequência alimentar para adultos da Região Metropolitana de Porto Alegre, Rio Grande do Sul, Brasil. Cad Saúde Pública. 2014;30(9):1837-48. http://dx.doi.org/10.1590/0102-31 $1 \times 00151313$

30. Masson LF, Neill GMC, Tomany JO, Simpson JA, Peace HS, Wei L, et al. Statistical approaches for assessing the relative validity of a food-frequency questionnaire: Use of correlation coefficients and the kappa statistic. Public Health Nutr. 2003;6(3):313-21. http://dx.doi.org/10.1079/PHN2002429

31. Freitas AF, Prado MA, Cação JC, Beretta D, Albertini S. Sarcopenia e estado nutricional de idosos: uma revisão da literatura. Arq Ciênc Saúde. 2015;22(1):9-13. http://dx.doi.org/10.17696/2318-3691.22.1.2015.19

32. Souza JD, Martins MV, Franco FS, Martinho KO, Tinôco AL. Padrão alimentar de idosos: caracterização e associação com aspectos socioeconômicos. Rev Bras Geriatr Gerontol. 2016;19(6):970-7. http://dx.dx.doi. org/10.1590/1981-22562016019.160035

33. Ministério da Saúde (Brasil). Secretaria de Atenção à Saúde. Guia alimentar para a população brasileira. 2. ed. Brasília: Ministério da Saúde; 2014.

34. Sousa KT, Mesquita LAS, Pereira LA, Azeredo ZM. Baixo peso e dependência funcional em idosos institucionalizados de Uberlândia (MG), Brasil. Ciênc \& Saúde Coletiva. 2014;19(8):3513-20. http://dx.doi. org/10.1590/1413-81232014198.21472013

35. Bergjohann P, Adami FS, Fassina P. Densidade energética das refeições oferecidas pelo serviço de nutrição e dietética de um hospital. Cad Pedag. 2016;13(3):37-46. http://dx.doi.org/10.22410/issn.1983-0882. v13i2a2016.1108

36. Mendes A, Pereira JL, Fisberg RM, Marchioni DML. Dietary energy density was associated with diet quality in Brazilian adults and older adults. Appetite. 2016;97:120-6. http://dx.doi.org/10.1016/j.appet.2015.11.025

37. Gorgulho BM, Lipi M, Marchioni DML. Qualidade nutricional das refeições servidas em uma unidade de alimentação e nutrição de uma indústria da região metropolitana de São Paulo. Rev Nutr. 2011;24(3):463-72. http://dx.doi.org/10.1590/S1415-52732011000300009

38. Malta MB, Papini SJ, Corrente JE. Avaliação da alimentação de idosos de município paulista: aplicação do Índice de Alimentação Saudável. Ciên Saúde Coletiva. 2013;18(2):377-84. 